\title{
Short- and long-term efficacy of forest thinning to mitigate drought impacts in mountain forests in the European Alps
}

\author{
Ché Elkin, ${ }^{1,2,4}$ Arnaud Giuggiola, ${ }^{1,3}$ Andreas Rigling, ${ }^{3}$ and Harald Bugmann ${ }^{1}$ \\ ${ }^{1}$ Swiss Federal Institute of Technology, ETH Zurich, Department of Environmental Sciences, Forest Ecology, Universitätstrasse 16 , \\ CH-8092 Zürich, Switzerland \\ ${ }^{2}$ University of Northern British Columbia, Ecosystem Science and Management, 3333 University Way, Prince George, \\ British Columbia V2N $4 Z 9$ Canada \\ ${ }^{3}$ WSL Swiss Federal Institute for Forest, Snow and Landscape Research, Zürcherstrasse 111, CH-8903 Birmensdorf, Switzerland
}

Abstract. In many regions of the world, drought is projected to increase under climate change, with potential negative consequences for forests and their ecosystem services (ES). Forest thinning has been proposed as a method for at least temporarily mitigating drought impacts, but its general applicability and longer-term impacts are unclear. We use a processbased forest model to upscale experimental data for evaluating the impacts of forest thinning in a drought-susceptible valley in the interior of the European Alps, with the specific aim of assessing (1) when and where thinning may be most effective and (2) the longer-term implications for forest dynamics.

Simulations indicate that forests will be impacted by climate-induced increases in drought across a broad elevation range. At lower elevations, where drought is currently prevalent, thinning is projected to temporarily reduce tree mortality, but to have minor impacts on forest dynamics in the longer term. Thinning may be particularly useful at intermediate and higher elevations as a means of temporarily reducing mortality in drought-sensitive species such as Norway spruce and larch, which currently dominate these elevations. However, in the longer term, even intense thinning will likely not be sufficient to prevent a climate change induced dieback of these species, which is projected to occur under even moderate climate change. Thinning is also projected to have the largest impact on long-term forest dynamics at intermediate elevations, with the magnitude of the impact depending on the timing and intensity of thinning. More intense thinning that is done later is projected to more strongly promote a transition to more drought-tolerant species.

We conclude that thinning is a viable option for temporarily reducing the negative drought impacts on forests, but that efficient implementation of thinning should be contingent on a site-specific evaluation of the near term risk of significant drought, and how thinning will impact the rate and direction of climate driven forest conversion.

Key words: adaptive management; climate change; drought; forest model; forest thinning; tree mortality.

\section{INTRODUCTION}

As a result of climate change, the frequency, intensity, and duration of drought events are projected to increase in many regions (Schar et al. 2004, Christensen et al. 2007, CH2011 2011, Rossler et al. 2012, Seneviratne et al. 2012), with potential negative implications for forests and forest-derived ecosystem services (ES; Allen et al. 2010, Hlasny et al. 2011, McDowell et al. 2011, Choat et al. 2012, Vicente-Serrano et al. 2013). Already over the past 30 years, the impacts of increased drought on forest ecosystems has been observed in regions such as the southwestern United States (Williams et al. 2010, Dietze and Moorcroft 2011, Michaelian et al. 2011, Anderegg et al. 2013a, Williams et al. 2013), south and central

Manuscript received 14 April 2014; revised 22 August 2014; accepted 2 October 2014; final version received 6 November 2014. Corresponding Editor: J. B. Bradford.

${ }^{4}$ E-mail: Che.Elkin@unbc.ca
Europe (Bigler et al. 2006, Galiano et al. 2010, Vacchiano et al. 2012, Rigling et al. 2013), Siberia (Kharuk et al. 2013), northeast Asia (Xu et al. 2012), and Australia (Matusick et al. 2013). Even in regions that are currently not water stressed, such as highelevation forests in the European Alps, projected changes in temperature and the timing and amount of precipitation have the potential to modify forest community composition (Booth et al. 2012, Kumagai and Porporato 2012, Levesque et al. 2013). Drought can directly impact tree recruitment (Shuman et al. 2009, Benavides et al. 2013, Galiano et al. 2013), growth (Eilmann et al. 2011, Eilmann and Rigling 2012, Levesque et al. 2013), and mortality (Bigler et al. 2006, Vacchiano et al. 2012, Vicente-Serrano et al. 2013), and these processes are the key drivers of changes in forest structure and composition (Galiano et al. 2010, Babst et al. 2013, Rigling et al. 2013). In addition, drought influences forests indirectly by altering the occurrence 
and severity of climate sensitive disturbances such as insects and pathogens (Jactel et al. 2012), or fire (Seidl et al. 2011b). Thus, forest dynamics can be altered by both the direct and indirect impacts of drought, with forest structure and the provisioning of forest ES being impacted at multiple spatial and temporal scales (Elkin et al. 2013).

In response to the projected increase in drought, and the potential negative impacts on forest ecosystems, forest managers may need to evaluate adaptive management practices to be used for mitigating drought impacts (Lindner 2000, Bolte et al. 2009, Parks and Bernier 2010, Seidl et al. 2011a). Over longer time frames, management such as planting more droughttolerant species or modifying management practices to facilitate the transition to more drought-adapted forests (Seidl et al. 2008, Temperli et al. 2012, Pretzsch et al. 2013) may be used to maintain forest ecosystem states and forest ecosystem dynamics within societally tolerable boundaries. However, converting from one forest composition to another will often take a long time and may still involve a period during which non-droughtadapted trees are predicted to exhibit dieback, with potentially negative consequences on forest ES (Courbaud et al. 2010, Anderegg et al. 2013b). An alternative adaptive management approach is to use techniques that will minimize the drought that forests experience at a local level while facilitating the transition from droughtsensitive forests to more drought-adapted forests.

Thinning of drought-susceptible forest stands has been suggested as a means of reducing drought impacts in the short term. Thinning decreases stem density and increases soil water availability for trees due to decreased stand transpiration and reduced canopy interception (Aussenac 2000). A number of studies have demonstrated that the drought stress experienced by individual trees is larger in dense stands (Weber et al. 2007, 2008, Zou et al. 2008). In addition, experimental forest thinnings conducted across a range of forest types have consistently demonstrated a reduction in evapotranspiration and an increase in soil moisture (Stogsdill et al. 1992, Bréda et al. 1995, Lesch and Scott 1997, McJannet and Vertessy 2001, McDowell et al. 2006, Jimenez et al. 2008, Lagergren et al. 2008, Moreno and Cubera 2008, Di Matteo et al. 2010), a decrease in tree mortality (Giuggiola et al. 2013), a facilitation of recruitment (Deal and Farr 1994, He and Barclay 2000, Otto et al. 2012, Olson et al. 2014), and higher growth of the remaining trees (Montero et al. 2001, Río et al. 2008). While forest thinning has been demonstrated to reduce drought stress in many systems, important questions remain regarding where and when thinning may be a suitable management response in droughtvulnerable forests, and what the long-term impacts of thinning may be on forest state and composition, particularly under novel climate conditions.

We use a process-based forest model to evaluate the potential to use thinning to mitigate negative climate change impacts in a dry inner-alpine forest under a range of future climate change scenarios. Forest models have a long tradition of being used to support forest management and more recently are being applied to evaluate how management and climate change may interact to influence long-term forest dynamics (Fontes et al. 2010, Temperli et al. 2012). We first modify a forest landscape model such that the relationship between stand density, stand evapotranspiration, and soil moisture available per tree is captured, based on experimental data from a thinning trial in Switzerland. We then evaluate model behavior using empirical data on the impact of forest thinning on the growth and mortality of Scots pine (Pinus sylvestris) stands growing in droughtsensitive low-elevation areas of our case study site. Lastly, using this modified model we project the combined impact of climate change and forest thinning on forest dynamics across a landscape that includes a broad elevation range, specifically focusing on the impacts of thinning on mortality and forest composition. In mountain forests, the impact of drought, and forest thinning, will be highly site specific within a landscape given the strong temperature and precipitation gradients along elevation gradients. Thus we focus on evaluating when and where thinning may be useful for mitigating drought impacts, and what the short- and long-term implications for forest dynamics at different elevations within a landscape are.

\section{Methods \\ Case study region}

We examined drought mitigation measures in the Saas Valley in Valais, Switzerland $\left(46^{\circ} 11^{\prime} \mathrm{N}\right.$ and $7^{\circ} 93^{\prime} \mathrm{E}$; elevation range $600-2290 \mathrm{~m}$ above sea level [a.s.1.]), a dry inner-alpine valley (mean annual temperature $8.6^{\circ} \mathrm{C}$ and precipitation $600 \mathrm{~mm}$ at $640 \mathrm{~m}$ a.s.l.). Drought is currently prevalent at lower elevations (600-1000 m a.s.1.) and forests there are dominated by droughttolerant pubescent oak (Quercus pubescens) and Scots pine (Pinus sylvestris) (Dobbertin et al. 2005, Bigler et al. 2006, Bolli et al. 2007). Between 1000-1200 m a.s.1., Scots pine and pedunculate oak (Quercus robur) are abundant, with more drought-intolerant deciduous species such as maple (Acer sp.) and European ash (Fraxinus excelsior) also present. Forests at higher elevations (1200-1800 m a.s.1.) are currently dominated by drought-intolerant Norway spruce (Picea abies), with a zone of Swiss stone pine-European larch (Pinus cembra-Larix decidua) forests towards the upper treeline (up to $\sim 2300 \mathrm{~m}$ a.s.1.). Climate projections suggest that the Saas valley region will experience increased summer temperatures and reduced precipitation, particularly during the summer months (Rebetez and Dobbertin 2004). Summer drought has already been demonstrated to be a driving factor for the death of Scots pine in the Valais (Bigler et al. 2006).

We simulated forests in the Valais at two scales. First, we simulated empirical plots in an experimental forest 
located in the main valley at an elevation of $620 \mathrm{~m}$ a.s.l. $\left(46^{\circ} 18^{\prime} \mathrm{N}\right.$ and $\left.7^{\circ} 36^{\prime} \mathrm{E}\right)$. Each simulation plot was 100 ha in size and was situated on the flat valley bottom. Second, we simulated an elevation transect in the Saas valley that ranged from 600 to $2400 \mathrm{~m}$ a.s.l. Because drought impacts predominantly occur at lower elevations between 600 and $1000 \mathrm{~m}$ a.s.l., we situated elevation bands at $50-\mathrm{m}$ increments, while between 1000 and $2400 \mathrm{~m}$ a.s.1., increments of $200 \mathrm{~m}$ were used. Elevation bands were subdivided into four treatment plots that were each 6.25 ha in size.

\section{Empirical forest thinning experiments}

Forest thinning trials that included "low," "medium," and "heavy" thinning treatments, as well as controls, had been set up in the experimental forest beginning in 1965. Treatment plots were 30 by $30 \mathrm{~m}$, with three replicates of each treatment. Control plots, which were established in 1974, had an initial basal area of $48.2 \mathrm{~m}^{2} /$ ha. The low, medium, and heavy thinning treatments resulted in forest basal area being reduced to 33.2, 22.3, and $11.5 \mathrm{~m}^{2} /$ ha, respectively. All treatments plots were re-thinned in 1971 and 1978. Stand-level measurements of basal area and mortality rate were made in 1991 and 2009. The impact of thinning on individual tree growth was measured by felling 10 trees per plot in 2010 and measuring their yearly radial stem growth. For a more detailed description of the thinning treatments and forest measurement see Giuggiola et al. (2013).

In 2010, plots were thinned again to achieve approximately the same basal area as reported after the initial thinning in 1965. At the beginning of the new thinning (2010), soil moisture was measured to evaluate the impact of thinning on soil moisture. For this, soil moisture was measured in one plot of each treatment by installing five decagon sensors (EC-TM) at $30 \mathrm{~cm}$ depth in a pentagon arrangement surrounding the logger (Em50R, Decagon Devices, Pullmann, Washington, USA) installed at the plot center. Soil moisture measurements were recorded hourly from April 2010 until February 2011.

\section{Forest landscape model}

We examined the impact of climate change and forest management on forest dynamics using the forest simulation model LandClim (Schumacher et al. 2004, 2006), a spatially explicit, process-based model that incorporates competition-driven stand dynamics and landscape-level disturbances to simulate forest dynamics on a landscape scale. LandClim was designed to examine the impact of climate change and forest management on forest development and structure (Schumacher and Bugmann 2006, Schumacher et al. 2006). The model has been tested in the Central Alps, North American Rocky Mountains, and Mediterranean forests, and has been used to simulate current as well as paleoecological (Colombaroli et al. 2010, Henne et al. 2011) and future forest dynamics (Schumacher and
Bugmann 2006). In particular, LandClim has been previously used to simulate both current and future forest dynamics in the case study region used here (Schumacher and Bugmann 2006, Schumacher et al. 2006, Elkin et al. 2013).

Here we provide a brief overview of the stand-scale formulations of the model; for further details see Schumacher et al. (2004). LandClim simulates forest growth in 25 by $25 \mathrm{~m}$ cells using simplified versions of tree recruitment, growth, and competition processes derived from those that are commonly used in gap models (Bugmann 2001). Forest growth is determined by climate variables, soil properties and topography, land use, and large-scale disturbances. In particular, precipitation, temperature, and soil moisture-holding capacity are used to calculate a drought index (Bugmann and Cramer 1998), which, in combination with growing degree-days and available light, influences tree recruitment, growth, and mortality. Forest dynamics within each cell are simulated by following tree age cohorts, where cohorts are characterized by the mean biomass of an individual tree and the number of trees in the cohort. Species-specific growth rates, growth forms, and tolerances to environmental conditions such as light and moisture availability, determine the relative competitive ability of each cohort of each species within a cell. As such, community composition and forest dynamics are an emergent property of the model. Individual cells are linked by the spatially explicit processes of seed dispersal and landscape disturbances. Succession processes, including tree growth and intrinsic mortality within each cell, are simulated on a yearly time step, while landscape-level processes, tree establishment, and forest management are simulated on a decadal time step.

\section{Vegetation-dependent drought index}

Available moisture for tree growth in LandClim is based on the drought index calculation of Bugmann and Cramer (1998), where evapotranspiration from the soil ( $\left.\mathrm{gE}_{\text {month }}\right)$ is represented as the lesser of the monthly evaporative demand from the soil (gD) or the monthly supply of water from the soil $(\mathrm{gS})$. As originally formulated, the supply of water is independent of the amount of vegetation present and is given by the equation

$$
\mathrm{gS}_{\text {month }}=\left(\min \left(c_{\mathrm{w}}, \text { soilMoisture }_{\max }\right)\right) \times \frac{\text { soilMoisture }_{\operatorname{month}}}{\text { soilMoisture }_{\max }}
$$

where $c_{\mathrm{W}}$ is the maximum rate of evapotranspiration from saturated soils under conditions of high demand (Prentice et al. 1993), soil Moisture $_{\max }$ is the moisture holding capacity of the soil, and soilMoisture month $_{\text {is the }}$ current soil moisture value.

Bugmann and Cramer's (1998) soil moisture model was designed to represent the soil water balance within a forest plot. In the context of a forest growth model the 


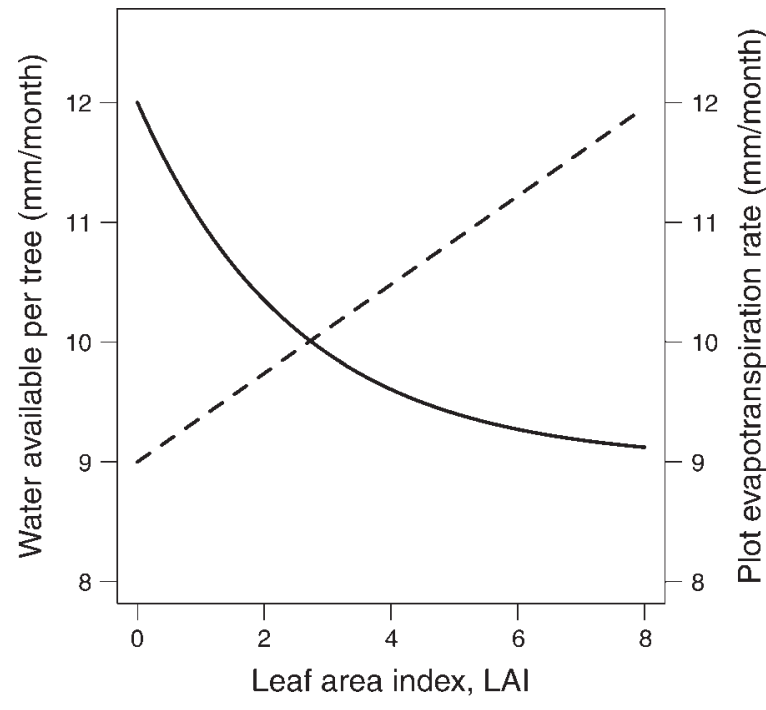

FIG. 1. Simulated decrease in soil moisture available per tree (solid line), and increasing plot evapotranspiration (dashed line), with increasing leaf area index (i.e., stand density).

soil moisture calculation therefore provides the dual functions of tracking the water budget of a plot, and serving as a proxy for the amount of water available to individual trees. We separated these two components to create a plot level drought index, which allows for plot level evapotranspiration to increase with increasing forest demand for water, and an individual tree drought index, which allows transpiration per tree to decrease with increasing competition. The amount of total transpiration from all trees on a plot and the amount of potential competition for soil moisture are assumed to be related to total leaf area index (LAI) within a plot (25 by $25 \mathrm{~m}$ ). Empirical studies have found LAI to be a good predictor of both annual and monthly transpiration (Bréda et al. 1995, Granier and Bréda 1996, Sarkkola et al. 2010).

The impact of stand thinning, and corresponding reductions in LAI, on individual tree transpiration has been examined across a range of tree species in different forest types (Black et al. 1980, Morikawa et al. 1986, McJannet and Vertessy 2001, Asbjornsen et al. 2007, Jimenez et al. 2008, Lagergren et al. 2008, Zou et al. 2008, Gea-Izquierdo et al. 2009, Abella 2010), with all studies reporting an initial increase in individual tree transpiration in thinned stands. In Quercus ilex stands, Moreno and Cubera (2008) found that daily tree transpiration, as estimated from sap flow density, decreased as fractional canopy cover increased. In Moreno and Cubera's (2008) experiments individual tree transpiration was maximal when stand canopy cover was low, and decreased to one-quarter (during spring) or one-half (during summer) of the maximum value when canopy cover approached $100 \%$.

To incorporate a representation of tree competition for soil moisture, we modified the individual drought index calculation by making the parameter $c_{\mathrm{w}}$ in Eq. $1 \mathrm{a}$ function of total plot LAI, thus rendering the supply of water conditional on forest cover. The function was defined such that water availability per tree reached its maximum in the absence of competition ( $\mathrm{LAI}=0)$, with the amount of water per tree being reduced to onequarter of the maximum when competition is high (maximum realized LAI $=8$, Fig. 1 ). Based on the empirical soil moisture data from Giuggiola et al. (2013) and the transpiration results of Moreno and Cubera (2008), we related water availability per individual $\left(c_{\mathrm{wLAI}}\right)$ to LAI using the following equation:

$$
c_{\mathrm{w} \text { LAI }}=c_{\mathrm{w} \min }+\left(c_{\mathrm{w} \max } \times c_{\mathrm{w} \min }\right) \times e^{-0.4 \mathrm{LAI}}
$$

where $c_{\mathrm{w} \max }=12$, the constant maximum rate of evapotranspiration used in Bugmann and Cramer's drought index calculation, and $c_{\mathrm{w} \min }=9$, corresponding to the relative reduction in tree transpiration measured by Moreno and Cubera (2008) as a component of total vegetation transpiration (Whitley et al. 2013, Zeppel 2013).

While the relationship between thinning and individual transpiration is well established, the relationship between stand density and stand level evapotranspiration is less clear. Direct measurements of stand evapotranspiration are difficult and few studies that have done so, normally focusing on eddy covariance measurements within small plots (Granier et al. 2000, Sun et al. 2008, Aranda et al. 2012, Whitley et al. 2013). Rather, most stand-level estimates of transpiration are based on up-scaling from individual tree transpiration measurements (Herbst et al. 2008, Kume et al. 2010, Dalsgaard et al. 2011). However, high uncertainty accompanies up-scaling in uneven-aged mixed species stands (Ford et al. 2007) due to species and life-stagespecific differences in transpiration (O'Grady et al. 2009, Macfarlane et al. 2010) and micro-site climate differences that impact vapor pressure deficit (Jung et al. 2011, Whitley et al. 2013). Based on the available data, regarding the impact of thinning on stand transpiration, no conclusive patterns emerge. Reduced transpiration has been reported in thinned sessile oak stands (Bréda et al. 1995), stands of mixed Scots pine and Norway spruce (Lagergren et al. 2008), and Chamaecyparis obtusa stands (Morikawa et al. 1986). Conversely, thinning was found to have little or no impact on stand transpiration in Douglas-fir (Black et al. 1980), loblolly pine (Stogsdill et al. 1992), and boreal Scots pine (Vesala et al. 2005).

To account for this uncertainty we conducted simulations with two different relationships between plot level evapotranspiration and LAI. In the first formulation, the maximum rate of plot evapotranspiration was assumed to be constant and independent of plot LAI (i.e., $c_{\mathrm{w}}=12$ as in Bugmann and Crammer's [1998] original formulation). In the second formulation, plotlevel evapotranspiration was assumed to increase 
linearly with LAI from a minimum $c_{\mathrm{w}}$ of 9 to a maximum of 12 (Fig. 1).

By incorporating competition for water we increased the value of the individual tree drought index, particularly at dry sites. In order to account for this, we increased the drought-tolerance parameter for each tree species by 0.05 to reflect the increase in the realized drought index values. We corroborated the new LAIdependent drought indices (Eq. 2) at 10 central European sites that represent a gradient of temperature and drought conditions (Appendix: Fig. A1), and which have previously been used for testing various forest models (Bugmann and Solomon 2000, Didion et al. 2009, Rasche et al. 2012). At each site, we varied LAI between 0 and 8. At the wettest sites (Davos, Grand Dixence, Huttwil, Bern) the calculated drought index was not impacted (Fig. A1), while at dry sites (Sion, Cottbus, Schwerin), tree competition was found to reduce water availability even at low values of LAI.

\section{Climate scenarios}

Regionally downscaled climate scenarios for Switzerland $(\mathrm{CH} 2011)$ from the Swiss Federal Institute of Technology (ETH) Center for Climate Systems Modeling $(\mathrm{C} 2 \mathrm{SM})$ were used. These projections range from moderate (RCP3PD; Meinshausen et al. 2011) to more severe scenarios (A1B, A2; Nakicenovic et al. 2000). Global climate projections corresponding to these scenarios were downscaled using high-resolution regional climate models (RCM) for Switzerland (van der Linden and Mitchell 2009, CH2011 2011, Fischer et al. 2011). Projected climate deviation values (absolute change in temperature, percent change in precipitation) were provided as ensemble values from these regional models for three reference periods (2020-2049, 20452074, 2070-2099). We used linear interpolation between the central year of the three climate periods $(2035,2060$, 2085) blocked by month, to calculate month-specific delta values for the period 1994 to 2100 .

Using these data, we created continuous monthly and daily weather data sets for the period 1994-2100, by randomly drawing weather data in year blocks from the reference period (1980-2009) and adding the monthspecific delta values. Reference period weather data were obtained from the MeteoSchweiz weather station at Visp in the Saas Valley. Weather data from 2100 to 2300 were simulated by assuming that delta values would remain constant at the 2100 level. Elevation-dependent temperature and precipitation lapse rates, calculated from climate data from weather stations at low and high elevations in the case study area, were used to calculate plot-specific climate data. Last, to account for the stochastic component of the weather data, we created 10 independent weather series for each climate scenario.

\section{Simulation experiments}

Our first set of simulations were conducted to evaluate the ability of the forest model to capture forest development and the impact of forest thinning trials on soil moisture, tree growth, and mortality that was observed in the experimental forest. Soil moisture conditions were initialized by simulating vegetation development from 1621 to 1920 using available climate conditions from 1900 to 2010. After this spin-up, we simulated the 1920-2010 period using weather data from the MeteoSchweiz weather station at Visp in the Saas Valley, and from 2010-2050 using climate data randomly drawn from the historical $1920-2010$ period. A clear cut was performed in 1920 followed by regeneration of Scots pine. This resulted in simulated forests in 1970 that had average basal areas of $42 \mathrm{~m}^{2} /$ ha and were dominantly composed of 50-yr-old Scots pine with an average DBH of $15.7 \mathrm{~cm}$. In comparison, the empirical experimental forest in 1965, the year of the first thinning treatment, had a basal area of $39 \mathrm{~m}^{2}$ ha and was dominated by 45 -yr-old Scots pine that ranged in size between 13 and $20 \mathrm{~cm}$ DBH. Ten independent replicate simulations were performed.

Due to the decadal time step of the simulated forest management, we were not able to exactly replicate the empirical thinnings that were done in 1965, 1971, and 1978. We approximated these management actions by simulating thinning in 1970 and 1980 such that, following the 1980 thinning, the average basal area of the simulated low, medium, and heavy thinning treatments were $39.7,26.0$, and $15.6 \mathrm{~m}^{2} /$ ha, respectively, which is broadly consistent with the empirical data (cf. further above). After the 1980 thinning, no additional forest management was simulated.

In a second set of simulations, we evaluated the potential use of forest thinning as means for mitigating the future increase in drought and the associated impacts on forests. These simulations were run along an elevation transect in the Saas valley and were initialized by simulating vegetation development from bare ground for an initial 300-yr spin-up period followed by a second 200-year spin-up period during which current forest management practices were simulated. In the Saas valley, the majority of forested areas provide protection against gravitational hazards such as rockfall. The structure and protective value of the forests is primarily maintained through the use of forest thinning, which is designed to promote regeneration. In our simulations, this management was approximated by assuming that, every decade, one-half of the stands that have reached a mature state would be managed. Within these stands, $80 \%$ of the trees that have reached a target $\mathrm{DBH}$ of $80 \mathrm{~cm}$ were removed. Following this spin-up period, which used climate data randomly drawn from the historical 1900-2010 period, we simulated 19002010 using the observed climate data and 2010-2300 using the three future climate scenarios. Current forest management practices were maintained in all simulations.

Previous studies (Elkin et al. 2013) and preliminary simulations of the 2010 to 2100 period suggest that 
climate change will result in large changes in forest community composition around the middle of the century. Thus we tested the impact of forest thinning treatments that were implemented either in 2020 or 2050. Each elevation band along the transect was divided into four equal-size compartments (6.25 ha) where one of the four thinning treatments was simulated (control, low, medium and heavy thinning). The intensity of the thinning operations was the same as applied to the empirical thinning in the experimental forest. Preceding and following the thinning treatments status-quo forest management was maintained.

\section{RESULTS}

Comparison of constant vs. LAI-dependent maximum plot transpiration rate

Simulations that included LAI-dependent maximum plot transpiration did not qualitatively differ from those that assumed constant maximum transpiration (Fig. 2 vs. Appendix: Fig. A2). However, LAI-dependent plot transpiration increased the impact of thinning on soil moisture retention (Fig. 2d vs. Fig. A2d), resulting in a larger increase in basal area increment between trees in heavily thinned vs. control plots (Fig. 2h vs. Fig. A2h), and a faster return to control plot levels of the basal area and annual mortality rates of thinned plots (Fig. $2 b$ vs. Fig. A2b, Fig. 2f vs. Fig. A2f). Because simulations using LAI-dependent plot transpiration more closely approximated the empirical thinning data, and the rate at which the forest recovered after the thinning, we focus on these results below. Results from simulations using constant maximum plot transpiration are included in the Appendix (Figs. A11-A14).

\section{Validation against empirical thinning experiments}

Basal area of the low and medium thinning treatments converged on the control plot basal area by 2010, while the basal area in the heavy thinning treatment was smaller, and still increasing, in 2010 (Fig. 2a). Corresponding with these empirical data, the simulated increase in basal area after the thinning treatments led to a recovery to simulated control values in the low- and medium-thinning treatments by the year 2000 and 2010 , respectively (Fig. 2b). The simulation results suggest that the heavily thinned stands will converge to the level of the simulated control plots by 2020. The simulated rate and timing of recovery of stand basal area after thinning therefore corresponded to the empirical data.

Empirical thinning resulted in a $0.7 \%, 3.1 \%$, and $4.9 \%$ increase in soil water content following low, medium, and heavy thinning, respectively (Fig. 2c). Correspondingly, in the simulations, the soil moisture index was $1.2 \%, 2.2 \%$, and $3.0 \%$ higher in the decade after thinning (Fig. 2d). While simulated soil moisture responded to the thinning treatments, the inter-decadal variation of soil moisture was rather large (Fig. 2d).

Between 1979 and 1990, the annual mortality rate of Scots pine in the empirical plots was reduced by $1.73 \%$ and $2.22 \%$ by the low and medium thinning, respectively (a decrease of $59 \%$ and $76 \%$, respectively, from the $2.94 \%$ mortality in the control plots), while heavy thinning resulted in mortality being reduced by $2.71 \%$ (a decrease of $92 \%$ from the mortality in the control plots; Fig. 2e). In the simulation experiments, the corresponding annual mortality rates in the decade after thinning were reduced by $0.9 \%, 1.9 \%$, and $2 \%$ (Fig. 2f), in accord with the empirical data. Simulated mortality rates returned to control levels by 1990 in the low thinning, by 2010 in the medium thinning, and were projected to not meet the control values in the heavy thinning trial until 2030.

The empirical heavy- and medium-thinning treatments resulted in a large increase in basal area growth following the initial thinning in 1965 (Fig. 2g). Empirical growth in the thinning treatments remained higher than in the control treatments until around 2005. In the simulation experiments, both heavy and medium thinning resulted in a large, though not as sudden, increase in annual basal area growth (Fig. 2h). Under all simulated treatments, growth above the control level was maintained until 2010. In contrast to the comparatively minor increase in empirical growth in the low thinning treatment, the simulation growth rate was markedly increased by low thinning intensity.

\section{Relative impact of thinning on light and moisture competition at low elevation (620 $m$ a.s.l.)}

Thinning treatments reduced competition for both water and light. In the model, the availability of both water and light for each tree decreased with increasing LAI, albeit with different slopes of the relationship (Fig. 3). The relative importance of reduced competition for water or light was projected to differ considerably between years due to annual differences in precipitation and the associated changes in realized importance of drought. During simulated wet years, such as 1990, competition for water was projected to be less important than competition for light in the control and lightthinning treatments (Fig. 3). In contrast, during dry years, the importance of competition for water was projected to exceed competition for light in all treatments except for the control plots with high LAI values.

\section{Projected impact of climate change along an elevation gradient in the Saas Valley}

For illustrative purposes, we focus on four elevation bands along the elevation gradient (Fig. 4) that represent areas that are currently dominated by different forest types and are expected to exhibit different sensitivities to climate change (cf. Elkin et al. 2013). At low elevations $(\sim 700 \mathrm{~m}$ a.s.1.) intermediate and severe climate change (scenarios A1B, A2) is projected to result in a reduction in forest biomass as the drought tolerance of Scots pine and drought-hardy oak is exceeded (Fig. 4a for A2 scenario; Appendix for other scenarios). 

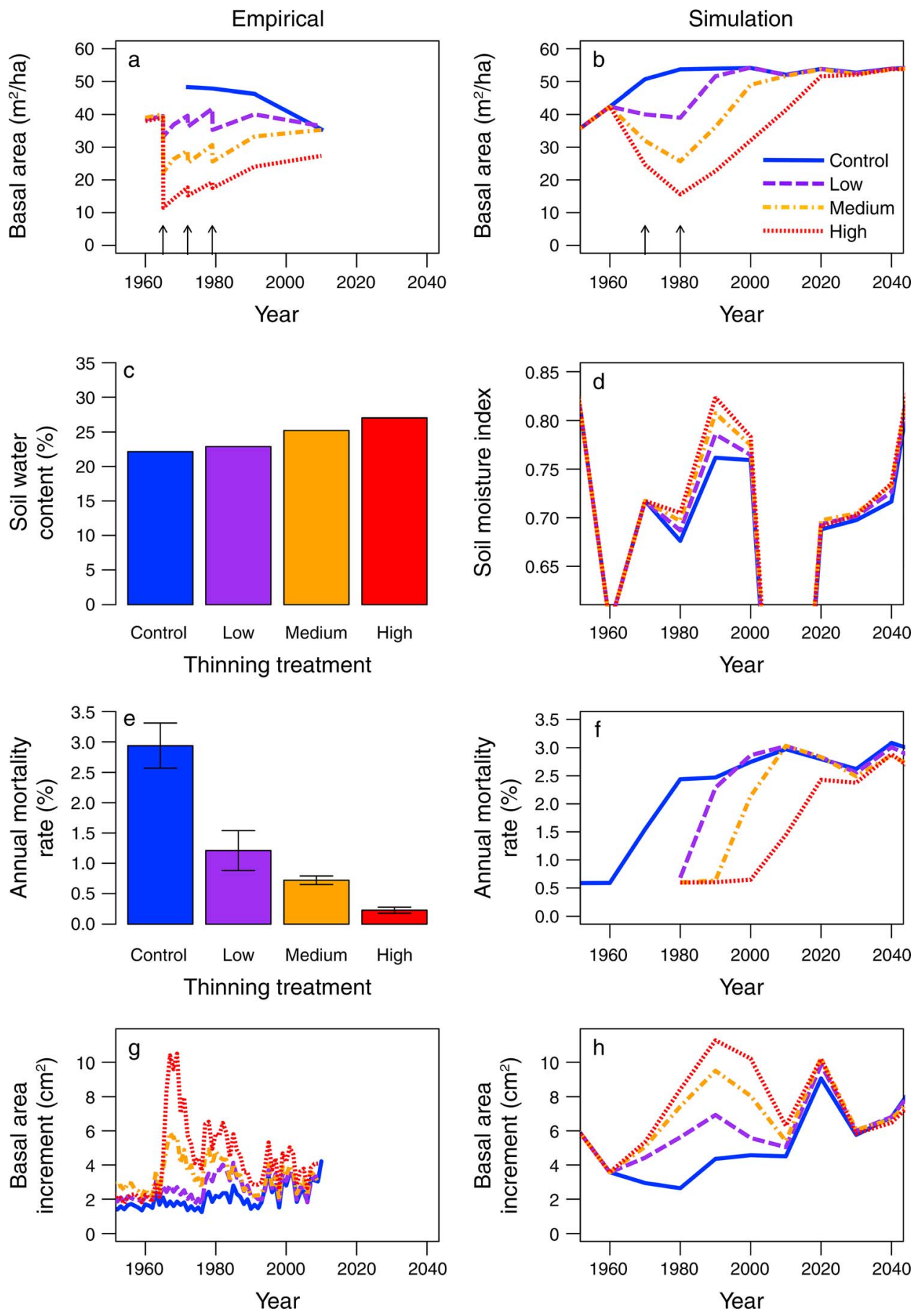

FIG. 2. Comparison of low (purple), medium (yellow), heavy (red), and control (blue) thinning treatments on forest basal area, soil water content, annual mortality rate of Scots pine, and annual basal area increment in (a, c, e, g) empirical and (b, d, f, h) simulated forest stands.

Mortality of Scots pine is projected to increase marginally around the middle of the 21 st century. Under moderate climate change (RCP3PD) at low elevations, little change in forest biomass or forest composition results. At $1000 \mathrm{~m}$ a.s.l., all climate scenarios project an increase in Scots pine and a reduction in drought-intolerant deciduous trees, with the largest changes not occurring until ca. 2100 (Fig. 4e). At intermediate elevations ( $\sim 1600 \mathrm{~m}$ a.s.1.), which are currently dominated by Norway spruce, all climate scenarios project a decrease in spruce biomass around the middle of the 21 st century and a transition to mixed 

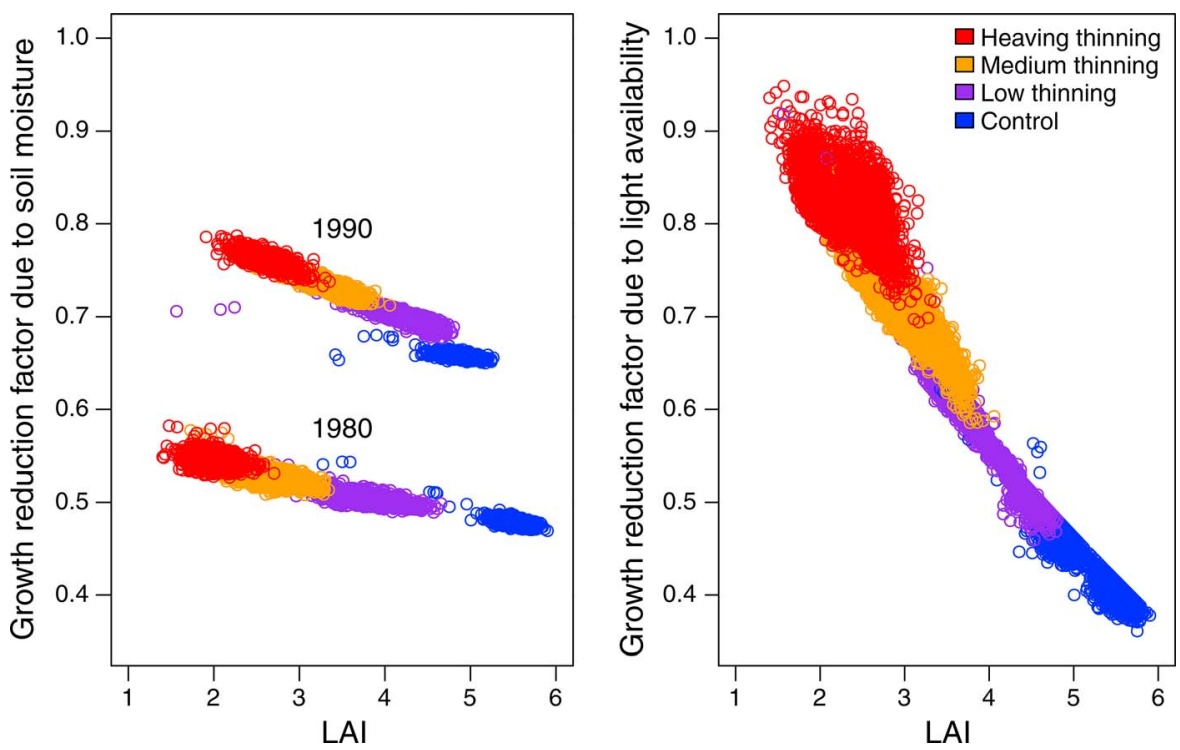

FIG. 3. Projected impact of low, medium, and heavy thinning and control treatments on simulated maximum Scots pine growth rate as it is limited by soil moisture and light availability (i.e., larger values represent larger reductions in potential growth). Thinning impacts on the light environment are reasonably static between years, while yearly variations in precipitation result in large yearly changes in moisture availability. The vertical axis of Fig. 3 shows the growth reduction factor (range between 0 and 1 ).

forests that have a considerable deciduous component (Fig. 4h). At these elevations the mortality rate of Norway spruce is projected to markedly increase during the latter part of the 21 st century and to remain high. At highest elevations ( $\sim 2000 \mathrm{~m}$ a.s.1.), deciduous species are projected to become more prevalent under the moderate and more severe climate scenarios, with a corresponding slight increase in the mortality rate of Norway spruce and a reduction in spruce biomass (Fig. $4 \mathrm{~m}$ ). While the three tested climate scenarios all result in similar projections of change, the timing of threshold responses by the forests, and the magnitude of the projected impacts, correspond with the severity of the climate projections (see Appendix for complete results).

\section{Projected impact of thinning treatments along the elevation gradient}

The projected impact of thinning on forest dynamics can be divided into the impacts on tree mortality and growth that are mediated through changes in the availability of water and light, and the impacts on forest dynamics that reflect the demographic changes imposed by thinning. Lower competition for resources and associated reductions in mortality are projected to occur during the first 10-20 years after thinning, as indicated by the period of reduced mortality following thinning (Fig. 4), and represent a relatively short-term response. In contrast, thinning-induced changes in forest demography are projected to continue to influence forest structure and development much longer (e.g., 150 years, cf. Fig. 4, Figs. A3-A14).

The impact of thinning is projected to vary considerably with elevation due to three interrelated factors: the current composition of the forest, differences in the dominant growth-limiting factors, and differences in how close the forests are to climate thresholds. At low elevations (700 $\mathrm{m}$ a.s.1.) and under all climate change scenarios, thinning is projected to reduce the mortality rate of Scots pine for approximately one decade before the rate returns to control plot levels (Fig. 4b, c, d). The comparatively severe drought conditions at low elevations mean that drought conditions frequently exceed what most species can tolerate, and the benefits of reduced competition for water do not alter the availability of soil moisture for a long time. As a result, thinning may be used in the short term to reduce Scots pine mortality, but it is projected to have little impact on forest composition (Fig. 4b, c, d). At a slightly higher elevations (1000 m a.s.1.; Fig. 4f, g, h) thinning is projected to have a lower impact on Scots pine mortality as this species is not as water stressed at this altitude, and Scots pine is projected to do better under climate change, at the expense of drought-intolerant deciduous species.

At still higher elevations (1600 $\mathrm{m}$ a.s.1.) thinning is projected to reduce Norway spruce mortality (Fig. $4 \mathrm{j}, \mathrm{k}, \mathrm{l}$ ), partially counteracting the large increase in spruce mortality rates that climate change is projected to induce between 2050 and 2100. In contrast to the relatively short-term impact of thinning at low elevations, thinning at $1600 \mathrm{~m}$ a.s.l. is projected to noticeably reduce spruce mortality for up to 50 years. However, following this reduced mortality period the simulations suggest that spruce mortality may be higher in medium and heavily thinned plots around 2100 , owing to the cumulative changes in temperature and precipitation 

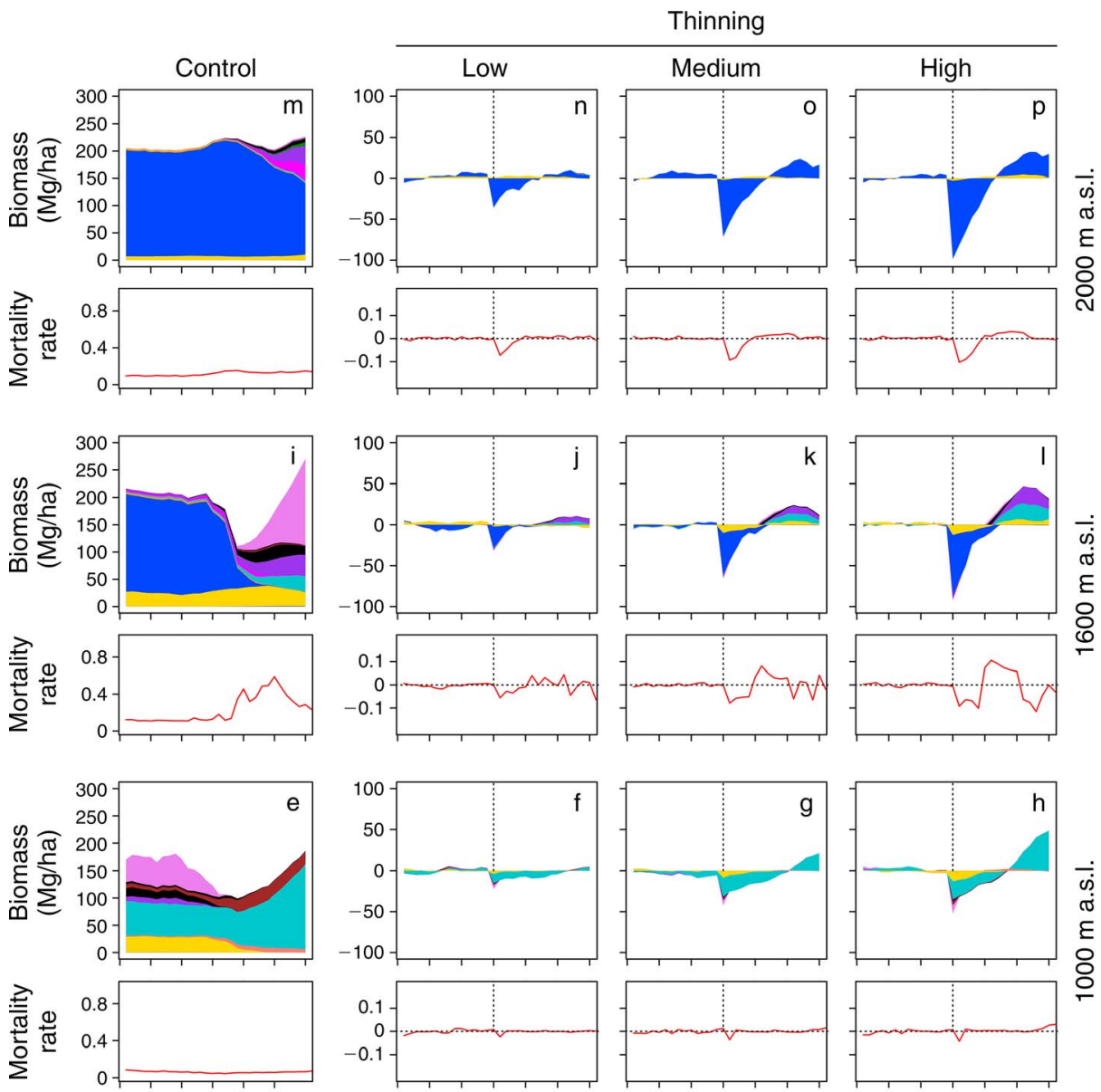

$\square$ Abies alba

$\square$ Larix decidua

$\square$ Picea abies

$\square$ Pinus cembra

$\square$ Pinus mugo

$\square$ Pinus sylvestris

$\square$ Acer pseudoplatanus

$\square$ Quercus petraea

$\square$ Quercus robur

- Acer campestre

- Acer platanoides

$\square$ Fraxinus excelsior

$\square$ Quercus pubescens

- Sorbus aria

$\square$ Tilia platyphyllos
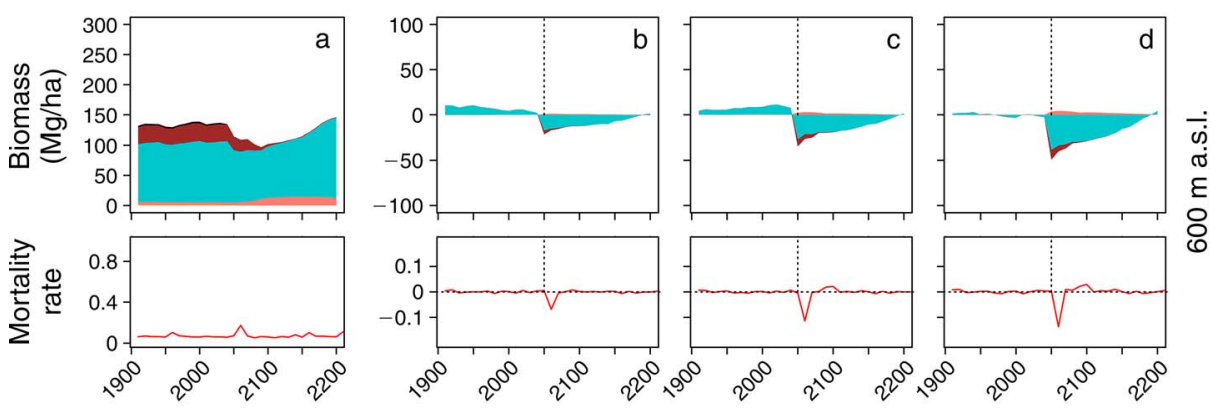

vax

FIG. 4. Projected impact of low, medium, and heavy thinning treatments performed in 2050, on tree species biomass and tree mortality rate at four elevation bands under the A2 climate scenario. Projected forest development with no thinning (i.e., control) but a continuation of status quo forest management is depicted in the first column (a, e, i, m). At the two lower elevations (600 and $1000 \mathrm{~m}$ above sea level [a.s.l.]) the mortality rate of Scots pine is shown, while at the higher elevations (1600 and $2000 \mathrm{~m}$ a.s.l.) the mortality rate of Norway spruce is shown. The projected impact of thinning treatments on species biomass and mortality rate (i.e., second, third, and fourth columns) are depicted as the thinning induced change in species biomass compared to the projected biomass and mortality rate in the same decade under the control treatment. Differences in species biomass are reported in $\mathrm{Mg} / \mathrm{ha}$ while mortality represents changes in the annual rate.

(Fig. 4k, 1). At these elevations thinning is also projected to facilitate the recruitment of species that are better adapted to the warmer and drier conditions that are expected for these altitudes (Fig. 4j, k. 1). The impact that thinning has on promoting the conversion to different tree species is projected to be largest under heavy thinning (Fig. 4l). At high elevations $(2000 \mathrm{~m}$ a.s.l.) thinning is also projected to reduce spruce mortality, but to have a much lower impact on forest composition (Fig. 4n, o, p). 
At some elevations the long-term impact of thinning on forest dynamics is projected to depend strongly on the timing of thinning. For example, under the A2 climate scenario at an elevation of $1600 \mathrm{~m}$ a.s.l., heavy thinning performed in 2020 is projected to facilitate a strong increase in larch after 2100. However, if the thinning is performed in 2050, the more advanced state of climate change is projected to favor an increase in Scots pine and oak rather than larch (cf. Fig. 41 with Fig. A81).

The rate at which the biomass of thinned plots recovers is projected to differ considerably between elevation bands. For example, spruce stands at $1600 \mathrm{~m}$ a.s.1. are projected to recover within several decades of the thinning treatment (Fig. 4j, k, l) while, at $1000 \mathrm{~m}$ a.s.l., thinning of Scots pine is projected to result in a protracted (50-100-year) reduction in forest biomass (Fig. 4f, g, h).

\section{Discussion}

The aim of adaptive management under increased drought can range from maintaining forests in their current state, to facilitating a transition to more drought-adapted species (Lindner 2000, Bolte et al. 2009, Parks and Bernier 2010, Seidl et al. 2011a). Our results suggest that forest thinning conducted with the purpose of reducing drought impacts can contribute to both of these objectives. In the short term (up to 20 years), forest thinning may be an effective management option for reducing mortality and increasing the growth of drought-stressed trees (Giuggiola et al. 2013, Sohn et al. 2013), while in the longer term (50-100 years), thinning can be used to facilitate a conversion to more drought-tolerant tree species. Here we discuss the factors that influence the efficacy of thinning and then consider the constraints and potential auxiliary benefits that will influence whether thinning is a suitable management option in response to drought.

\section{Thinning effects are site specific}

Our simulations project that, in our case study, climate change will impact forests throughout the region, but with the magnitude and timing of the impacts being highly elevation specific. Currently, drought is a dominant factor affecting forest at elevations $<1000 \mathrm{~m}$ a.s.1. (Dobbertin et al. 2005, Bigler et al. 2006). By the latter part of the century, drought is projected to become an important factor influencing forest dynamics at intermediate and higher elevations as well, even under moderate climate change scenarios.

At all elevations, our results suggest that thinning can be effective at reducing tree mortality. Low and intermediate thinning is projected to decrease both Scots pine and Norway spruce mortality, whereas particularly at higher elevations only marginal reductions in mortality are projected under more intense thinning. These simulation results correspond with the empirical data of Giuggiola et al. (2013) who found that low and intermediate thinning was sufficient to consid- erably improve soil moisture availability. However, Giuggiola et al. (2013) also noted that forest regeneration was most impacted by intermediate and heavy thinning, likely mediated by improvements in light conditions rather than soil moisture, thereby suggesting that heavy thinning will have larger long-term impacts of forest development.

Our results suggest that a climate-related increase in drought at intermediate and higher elevations can induce strong changes in forest properties, as these sites currently are mesic. This corresponds with recent work suggesting that trees at mesic sites can be more sensitive to changes in precipitation compared to those at xeric sites (Levesque et al. 2013). Our simulations further indicate that these regions, where drought-sensitive Norway spruce and larch are projected to decline in the future, are the areas where forest thinning to reduce drought stress may be most beneficial in the short term. However, in the longer term, thinning treatments are not projected to be able to prevent the dieback of spruce at intermediate elevations $(\sim 1600 \mathrm{~m}$ a.s.l. $)$ even under moderate climate change.

Thinning is projected to be more effective at maintaining larch at lower elevations $(\sim 1000 \mathrm{~m}$ a.s.1.) under moderate climate change, but is also projected to be ineffective under intermediate or more severe climate scenarios. The projected inability of thinning to prevent the dieback of spruce and larch concurs with empirical studies that suggest both of these species to be currently near their physiological limits on dry sites at lower elevation in the Central Alps (Zweifel et al. 2009, Eilmann and Rigling 2012, Schuster and Oberhuber 2013).

\section{The timing of thinning matters}

Simulations indicate that the positive impact of a single thinning application on water and light availability will only last for a couple of decades, particularly at low-elevation sites. The timing of a thinning can therefore strongly impact the realized benefits. Under more severe climate change scenarios, dieback of Norway spruce and larch is projected to occur between 2050 and 2100. Thus, the benefits of thinning performed in 2020 are lower than those achieved if thinning is performed in 2050. Even at low elevations, where drought is currently negatively impacting Scots pine, thinning in 2050 is projected to have a larger impact due to the advanced state of climate change at that time.

The timing of thinning is also likely to have a large impact on the long-term effects on forest dynamics. This is best exemplified at intermediate elevations where heavy thinning performed in 2020 is projected to strongly favor the development of larch between 2070 and 2150, while the same thinning conducted in 2050 is projected to favor the development of more droughttolerant species as a result of the higher temperature and reduced water availability.

While our work focused on the impact of individual thinning applications, long-term silvicultural experi- 
ments analyzed by D'Amato et al. (2013) indicate that repeated thinning, implemented to maintain a forest stand at constant stem density, can maintain increased drought resistance over a longer time period. However, D'Amato et al. (2013) also found that while the repeated thinning of young stands can maintain drought resistance, the drought resistance of these same stands can be adversely affected as they become older. These longer-term impacts of repeated thinning likely reflect the impact that thinning has on tree size and architecture, and highlights that an evaluation of the long-term benefits of thinning needs to consider both the longer-term impacts on forest dynamics and tree physiology.

\section{Importance of climate seasonality for forest responses}

Between 1983 and 2009, at low-elevation sites in the Valais, a reduction in Scots pine and an increase in drought-tolerant pubescent oak has been observed (Rigling et al. 2013). This shift in species composition reflects drought-related mortality of Scots pine and strong recruitment of oak at warm dry sites. Corresponding with these results, in the model, pubescent oak is parameterized as being more drought tolerant than Scots pine. However, under intermediate and more severe climate change simulations the biomass of pubescent oak is projected to decrease strongly while the projected negative impact on Scots pine is comparatively smaller.

This seeming discrepancy between simulations and the documented increase in pubescent oak at dry sites in the Valais (Rigling et al. 2013) reflects (1) the season-specific variation in projected changes in precipitation in the climate scenarios and (2) the model assumption that drought in deciduous species is determined primarily by summer precipitation, while coniferous species can potentially use precipitation that occurs in other seasons provided that temperature is high enough (Bugmann and Cramer 1998, Bugmann and Solomon 2000). Specifically, regional climate projections for the Valais suggest that while summer precipitation is projected to noticeably decrease, precipitation during the spring (i.e., March, April) and to a lesser extent the fall (i.e., October, November) is projected to increase (CH2011 2011). Therefore, the drought levels that Scots pine experiences in the model are lower than those impacting pubescent oak. While our projections of a decrease in pubescent oak should be viewed with considerable caution, these results highlight that changes in the timing of precipitation can be just as important as changes in seasonal amounts regarding the impacts on the relative competitive ability of different species (Eilmann et al. 2009).

Thinning as a reactive or preemptive strategy to maintain forests properties and ES

Variation in monthly and yearly precipitation can be high, such that the drought experienced by forests is highly variable and difficult to predict (Ciais et al. 2005, Rebetez et al. 2006). Due to the uncertainty associated with drought occurrence and the concomitant uncertainty related to the benefits of thinning, forest managers will need to decide whether thinning is best implemented as a reactive response to observed drought or as a preemptive strategy (cf. Temperli et al. 2012).

There are costs and risks associated with both approaches. With reactive management, the costs to monitor forest condition and to maintain the resources necessary to implement thinning if needed must be taken into account, and the risk that substantial negative drought impacts may occur prior to the benefits of thinning. In contrast, preemptive thinning carries the risk that thinning is performed at a site where substantial drought may not occur during the relevant period (von Detten 2011). However, if preemptive thinning is employed, the benefits to tree growth and vigor that are achieved through improved light conditions, which are comparatively static relative to yearly fluctuations in water availability, will still be realized. Therefore, whether a preemptive or reactive thinning strategy is used should depend on the degree of confidence that forest managers have about drought as a driving factor of forest dynamics in the short term, and an evaluation of the auxiliary benefits that thinning may provide, such as improved light conditions, higher habitat quality, and possibly also higher biodiversity (Neill and Puettmann 2013), which will still be realized even if the benefits regarding drought mitigation are not fulfilled.

Another key challenge for forest managers will be trying to find an acceptable balance between thinning that is sufficiently intense to result in mortality reduction, but small enough to not have strong negative impacts on stand stability just after the intervention and current forest ES state, or to potentially alter long-term forest demography. In the Valais case study, one of the main ES that forests provide is protection against gravitational hazards such as rockfall and avalanches (Brang et al. 2006, Bebi et al. 2009). As such, management that will mitigate the projected large dieback of spruce forests at intermediate elevations may be essential for maintaining these ES. However, the forest characteristic that predominantly determines the forests' ability to provide protection against gravitational hazards, and rockfall in particular, are basal area and tree numbers (Dorren et al. 2005, Bigot et al. 2009). Therefore, while thinning may decrease the mortality risk of remaining trees it will also weaken the protective ability of forests (Schonenberger et al. 2005), such that a short-term trade-off between drought mitigation and ES maintenance may result.

\section{Ancillary benefits of thinning}

The short time window during which a single thinning will have a positive effect $(\sim 20$ years) suggests that thinning may be most suitable as a short-term response 
to negative climate impacts and may function as a stopgap response while longer-term adaptive measures are implemented. However, our simulations do not include any acclimation responses by the trees subjected to drought. Past studies have found that some trees exhibit phenotypic plasticity in their physiology and life history in response to drought (Magnani et al. 2002, Brunner et al. 2009, Niinemets 2010, Creese et al. 2011). For example, Mencuccini and Grace (Mencuccini and Grace 1995) and Mencuccini and Bonosi (Mencuccini and Bonosi 2001) found that Scots pine trees subjected to sustained drought decrease their leaf area to sapwood area ratio. Similarly, sustained drought has been shown to impact the root-to-shoot ratio of individual trees (Aroca 2012), to decrease the amount of fine roots (Brunner et al. 2009), and to promote the development of smaller canopies (Eilmann et al. 2013), shorter shoots and needles (Rigling et al. 2010). If these acclimation mechanisms are realized in Scots pine and Norway spruce, a thinning treatment that reduces tree mortality rates in the short term may potentially allow the trees sufficient time to alter their physiology and life history in response to increased drought, thereby providing longer term benefits.

In addition to directly decreasing mortality and increasing tree growth, forest thinning has the potential to temporary increase the risk of storm and snow damage, but also reduce the occurrence and/or severity of climate sensitive disturbances such as insects and fire. Climate change may directly increase the importance of forest pathogens and insects by decreasing winter mortality and increasing the number of generations produced per year (Logan and Bentz 1987, Wermelinger and Seifert 1999), or indirectly by increasing stress and decreasing trees resistance to pathogen attacks (Evangelista et al. 2011, McDowell et al. 2011, Temperli et al. 2013). Drought in particular increases the susceptibility of trees to pine mistletoe (Dobbertin and Rigling 2006) and bark beetles (Dobbertin et al. 2007, Wermelinger et al. 2008).

If mortality pressure from forest pathogens and insects is more prevalent in the future the positive benefits of thinning, as mediated through improved tree vigor and increased resistance to insect and pathogen attack (Dobbertin et al. 2007), may be larger than our results suggest. Increased temperature and decreased moisture will also likely increase the risk of forest fires (Zumbrunnen et al. 2009, Pechony and Shindell 2010). If this occurs, thinning can have the dual benefit of increasing vegetation moisture such that the risk of fire ignition and spread is reduced, and decreasing the amount of available fuel, which reduces fire intensity (Gonzalez et al. 2005, Crecente-Campo et al. 2009, Jactel et al. 2009, Butler et al. 2013).

\section{Conclusions}

The relatively short period during which thinning will decrease drought stress in trees (up to 20 years) implies that using forest thinning as a preemptive management strategy to increase forest resistance to future climate change will only be appropriate in regions where there is a high probability of drought stress. In such regions, thinning can be used to temporarily maintain high-value forests and forest ES, thereby potentially providing time to implement more effective and rigorous climate adaptive strategies. However, in the longer term thinning will likely be unable to prevent climate change driven alteration to forest properties.

Moderate thinning that is performed before drought becomes severe will function better at maintaining forest in their current state, but will have less impact with regard on facilitating a transition to more droughttolerant species in the intermediate to longer term. Conversely, heavy thinning that is performed later has the potential to be less effective at increasing drought resistance of the current forest, but will be more effective at aiding the development of drought-tolerant species. However, heavy thinning can temporary reduce stand stability and therefore increase the short-term risk of severe damages. e.g., by storms and snow load. Therefore, forest managers need to consider the temporal trade-offs in forests ES provisioning that will likely be realized when evaluating the timing and intensity of forest thinning.

\section{ACKNOWLEDGMENTS}

This research was supported by funding from the MOUNTLAND project through the Competence Center "Environment and Sustainability" (CCES) of the ETH Domain, and the Forest and Climate Change Program funded by the Swiss Office for the Environment and operated by the Swiss Federal Research Institute WSL. We thank the ETH Center for Climate Systems Modeling (C2SM) who provided the climate scenarios.

\section{Literature Cited}

Abella, S. 2010. Thinning pine plantations to reestablish oak openings species in northwestern Ohio. Environmental Management 46:391-403.

Allen, C. D., et al. 2010. A global overview of drought and heat-induced tree mortality reveals emerging climate change risks for forests. Forest Ecology and Management 259:660684.

Anderegg, L. D. L., W. R. L. Anderegg, J. Abatzoglou, A. M. Hausladen, and J. A. Berry. 2013a. Drought characteristics' role in widespread aspen forest mortality across Colorado, USA. Global Change Biology 19:1526-1537.

Anderegg, W. R. L., J. M. Kane, and L. D. L. Anderegg. $2013 b$. Consequences of widespread tree mortality triggered by drought and temperature stress. Nature Climate Change $3: 30-36$.

Aranda, I., A. Forner, B. Cuesta, and F. Valladares. 2012. Species-specific water use by forest tree species: From the tree to the stand. Agricultural Water Management 114:67-77.

Aroca, R. 2012. Plant responses to drought stress: from morphological to molecular features. Springer, Berlin, Germany.

Asbjornsen, H., M. D. Tomer, M. Gomez-Cardenas, L. A. Brudvig, C. M. Greenan, and K. Schilling. 2007. Tree and stand transpiration in a Midwestern bur oak savanna after elm encroachment and restoration thinning. Forest Ecology and Management 247:209-219. 
Aussenac, G. 2000. Interactions between forest stands and microclimate: ecophysiological aspects and consequences for silviculture. Annals of Forest Science 57:287-301.

Babst, F., et al. 2013. Site- and species-specific responses of forest growth to climate across the European continent. Global Ecology and Biogeography 22:706-717.

Bebi, P., D. Kulakowski, and C. Rixen. 2009. Snow avalanche disturbances in forest ecosystems - state of research and implications for management. Forest Ecology and Management 257:1883-1892.

Benavides, R., S. G. Rabasa, E. Granda, A. Escudero, J. A. Hodar, J. Martinez-Vilalta, A. M. Rincon, R. Zamora, and F. Valladares. 2013. Direct and indirect effects of climate on demography and early growth of Pinus sylvestris at the rear edge: changing roles of biotic and abiotic factors. PLoS ONE 8. http://dx.doi.org/10.1371/journal.pone.0059824

Bigler, C., O. Bräker, H. Bugmann, M. Dobbertin, and A. Rigling. 2006. Drought as an inciting mortality factor in Scots pine stands of the Valais, Switzerland. Ecosystems 9:330-343.

Bigot, C., L. K. A. Dorren, and F. Berger. 2009. Quantifying the protective function of a forest against rockfall for past, present and future scenarios using two modelling approaches. Natural Hazards 49:99-111.

Black, T. A., U. Nnyamah, and C. S. Tan. 1980. Transpiration rate of Douglas fir trees in thinned and unthinned stands. Canadian Journal of Soil Science 60:625-631.

Bolli, J. C., A. Rigling, and H. Bugmann. 2007. The influence of changes in climate and land-use on regeneration dynamics of Norway spruce at the treeline in the Swiss Alps. Silva Fennica 41:55-70.

Bolte, A., C. Ammer, M. Lof, P. Madsen, G. J. Nabuurs, P. Schall, P. Spathelf, and J. Rock. 2009. Adaptive forest management in central Europe: climate change impacts, strategies and integrative concept. Scandinavian Journal of Forest Research 24:473-482.

Booth, R. K., S. T. Jackson, V. A. Sousa, M. E. Sullivan, T. A. Minckley, and M. J. Clifford. 2012. Multi-decadal drought and amplified moisture variability drove rapid forest community change in a humid region. Ecology 93:219-226.

Brang, P., W. Schonenberger, M. Frehner, R. Schwitter, J. J. Thormann, and B. Wasser. 2006. Management of protection forest in the European Alps: an overview. Forest Snow Landscape Research 80:23-44.

Bréda, N., A. Granier, and G. Aussenac. 1995. Effects of thinning on soil and tree water relations, transpiration and growth in an oak forest (Quercus petraea (Matt.) Liebl.). Tree Physiology 15:295-306.

Brunner, I., E. G. Pannatier, B. Frey, A. Rigling, W. Landolt, S. Zimmermann, and M. Dobbertin. 2009. Morphological and physiological responses of Scots pine fine roots to water supply in a dry climatic region in Switzerland. Tree Physiology 29:541-550.

Bugmann, H. 2001. A review of forest gap models. Climatic Change 51:259-305.

Bugmann, H., and W. Cramer. 1998. Improving the behaviour of forest gap models along drought gradients. Forest Ecology and Management 103:247-263.

Bugmann, H. K. M., and A. M. Solomon. 2000. Explaining forest composition and biomass across multiple biogeographical regions. Ecological Applications 10:95-114.

Butler, B. W., R. D. Ottmar, T. S. Rupp, R. Jandt, E. Miller, K. Howard, R. Schmoll, S. Theisen, R. E. Vihnanek, and D. Jimenez. 2013. Quantifying the effect of fuel reduction treatments on fire behavior in boreal forests. Canadian Journal of Forest Research 43:97-102.

CH2011. 2011. Swiss climate change scenarios. CH2011, Zurich, Switzerland.

Choat, B., et al. 2012. Global convergence in the vulnerability of forests to drought. Nature 491:752-755.
Christensen, J. H., et al. 2007. Regional climate projections. Pages 847-940 in S. Solomon, D. Qin, M. Manning, Z. Chen, M. Marquis, K. B. Averyt, M. Tignor, and H. L. Miller, editors. Climate change 2007: the physical science basis. Contribution of Working Group I to the Fourth Assessment Report of the Intergovernmental Panel on Climate Change. Cambridge University Press, Cambridge, UK.

Ciais, P., et al. 2005. Europe-wide reduction in primary productivity caused by the heat and drought in 2003 . Nature 437:529-533.

Colombaroli, D., P. D. Henne, P. Kaltenrieder, E. Gobet, and W. Tinner. 2010. Species responses to fire, climate and human impact at tree line in the Alps as evidenced by palaeoenvironmental records and a dynamic simulation model. Journal of Ecology 98:1346-1357.

Courbaud, B., G. Kunstler, X. Morin, and T. Cordonnier. 2010. What is the future of the ecosystem services of the Alpine forest against a backdrop of climate change? Journal of Alpine Research 98:412-425.

Crecente-Campo, F., A. Pommerening, and R. RodriguezSoalleiro. 2009. Impacts of thinning on structure, growth and risk of crown fire in a Pinus sylvestris L. plantation in northern Spain. Forest Ecology and Management 257:19451954.

Creese, C., A. M. Benscoter, and H. Maherali. 2011. Xylem function and climate adaptation in Pinus. American Journal of Botany 98:1437-1445.

Dalsgaard, L., T. N. Mikkelsen, and A. Bastrup-Birk. 2011. Sap flow for beech (Fagus sylvatica L.) in a natural and a managed forest - effect of spatial heterogeneity. Journal of Plant Ecology 4:23-35.

D'Amato, A. W., J. B. Bradford, S. Fraver, and B. J. Palik. 2013. Effects of thinning on drought vulnerability and climate response in north temperate forest ecosystems. Ecological Applications 23:1735-1742.

Deal, R. L., and W. A. Farr. 1994. Composition and development of conifer regeneration in thinned and unthinned natural stands of western hemlock and Sitka spruce in southeast Alaska. Canadian Journal of Forest Research 24:976-984.

Di Matteo, G., P. De Angelis, E. Brugnoli, P. Cherubini, and G. Scarascia-Mugnozza. 2010. Tree-ring delta C-13 reveals the impact of past forest management on water-use efficiency in a Mediterranean oak coppice in Tuscany (Italy). Annals of Forest Science 67:510-518.

Didion, M., A. D. Kupferschmid, M. J. Lexer, W. Rammer, R. Seidl, and H. Bugmann. 2009. Potentials and limitations of using large-scale forest inventory data for evaluating forest succession models. Ecological Modelling 220:133-147.

Dietze, M. C., and P. R. Moorcroft. 2011. Tree mortality in the eastern and central United States: patterns and drivers. Global Change Biology 17:3312-3326.

Dobbertin, M., P. Mayer, T. Wohlgemuth, E. FeldmeyerChriste, U. Graf, N. E. Zimmermann, and A. Rigling. 2005. The decline of Pinus sylvestris L. forests in the Swiss Rhone Valley - a result of drought stress? Phyton-Annales Rei Botanicae 45:153-156.

Dobbertin, M., and A. Rigling. 2006. Pine mistletoe (Viscum album ssp. austriacum) contributes to Scots pine (Pinus sylvestris) mortality in the Rhone valley of Switzerland. Forest Pathology 36:309-322.

Dobbertin, M., B. Wermelinger, C. Bigler, M. Bürgi, M. Carron, B. Forster, U. Gimmi, A. Rigling, and E. Oksanen. 2007. Linking increasing drought stress to Scots pine mortality and bark beetle infestations. Scientific World Journal 7:231-239.

Dorren, L. K. A., F. Berger, C. le Hir, E. Mermin, and P. Tardif. 2005. Mechanisms, effects and management implications of rockfall in forests. Forest Ecology and Management 215:183-195. 
Eilmann, B., M. Dobbertin, and A. Rigling. 2013. Growth response of Scots pine with different crown transparency status to drought release. Annals of Forest Science 70:685693.

Eilmann, B., and A. Rigling. 2012. Tree-growth analyses to estimate tree species' drought tolerance. Tree Physiology 32:178-187.

Eilmann, B., R. Zweifel, N. Buchmann, P. Fonti, and A. Rigling. 2009. Drought-induced adaptation of the xylem in Scots pine and pubescent oak. Tree Physiology 29:10111020.

Eilmann, B., R. Zweifel, N. Buchmann, E. G. Pannatier, and A. Rigling. 2011. Drought alters timing, quantity, and quality of wood formation in Scots pine. Journal of Experimental Botany 62:2763-2771.

Elkin, C., A. G. Gutiérrez, S. Leuzinger, C. Manusch, C. Temperli, L. Rasche, and H. Bugmann. 2013. A $2{ }^{\circ} \mathrm{C}$ warmer world is not safe for ecosystem services in the European Alps. Global Change Biology 19:1827-1840.

Evangelista, P. H., S. Kumar, T. J. Stohlgren, and N. E. Young. 2011. Assessing forest vulnerability and the potential distribution of pine beetles under current and future climate scenarios in the Interior West of the US. Forest Ecology and Management 262:307-316.

Fischer, A. M., A. P. Weigel, C. M. Buser, R. Knutti, H. R. Künsch, M. A. Liniger, C. Schär, and C. Appenzeller. 2011. Climate change projections for Switzerland based on a Bayesian multi-model approach. International Journal of Climatology 32:2348-2371.

Fontes, L., J. D. Bontemps, H. Bugmann, M. Van Oijen, C. Gracia, K. Kramer, M. Lindner, T. Rotzer, and J. P. Skovsgaard. 2010. Models for supporting forest management in a changing environment. Forest Systems 19:8-29.

Ford, C. R., R. M. Hubbard, B. D. Kloeppel, and J. M. Vose. 2007. A comparison of sap flux-based evapotranspiration estimates with catchment-scale water balance. Agricultural and Forest Meteorology 145:176-185.

Galiano, L., J. Martinez-Vilalta, M. Eugenio, I. Granzow-de la Cerda, and F. Lloret. 2013. Seedling emergence and growth of Quercus spp. following severe drought effects on a Pinus sylvestris canopy. Journal of Vegetation Science 24:580-588.

Galiano, L., J. Martinez-Vilalta, and F. Lloret. 2010. Droughtinduced multifactor decline of Scots pine in the Pyrenees and potential vegetation change by the expansion of co-occurring oak species. Ecosystems 13:978-991.

Gea-Izquierdo, G., D. Martín-Benito, P. Cherubini, and I. Cañellas. 2009. Climate-growth variability in Quercus ilex L. west Iberian open woodlands of different stand density. Annals of Forest Science 66:802-814.

Giuggiola, A., H. Bugmann, A. Zingg, M. Dobbertin, and A. Rigling. 2013. Reduction of stand density increases drought resistance in xeric Scots pine forests. Forest Ecology and Management 310:827-835.

Gonzalez, J., M. Palahi, and T. Pukkala. 2005. Integrating fire risk considerations in forest management planning in Spain - a landscape level perspective. Landscape Ecology 20:957-970.

Granier, A., P. Biron, and D. Lemoine. 2000. Water balance, transpiration and canopy conductance in two beech stands. Agricultural and Forest Meteorology 100:291-308.

Granier, A., and N. Bréda. 1996. Modelling canopy conductance and stand transpiration of an oak forest from sap flow measurements. Annals of Forest Science 53:537-546.

He, F., and H. J. Barclay. 2000. Long-term response of understory plant species to thinning and fertilization in a Douglas-fir plantation on southern Vancouver Island, British Columbia. Canadian Journal of Forest Research 30:566-572.

Henne, P. D., C. M. Elkin, B. Reineking, H. Bugmann, and W. Tinner. 2011. Did soil development limit spruce (Picea abies) expansion in the Central Alps during the Holocene? Testing a palaeobotanical hypothesis with a dynamic landscape model. Journal of Biogeography 38:933-949.

Herbst, M., P. T. W. Rosier, M. D. Morecroft, and D. J. Gowing. 2008. Comparative measurements of transpiration and canopy conductance in two mixed deciduous woodlands differing in structure and species composition. Tree Physiology 28:959-970.

Hlasny, T., Z. Barcza, M. Fabrika, B. Balazs, G. Churkina, J. Pajtik, R. Sedmak, and M. Turcani. 2011. Climate change impacts on growth and carbon balance of forests in Central Europe. Climate Research 47:219-236.

Jactel, H., et al. 2009. The influences of forest stand management on biotic and abiotic risks of damage. Annals of Forest Science 66:701-719.

Jactel, H., J. Petit, M.-L. Desprez-Loustau, S. Delzon, D. Piou, A. Battisti, and J. Koricheva. 2012. Drought effects on damage by forest insects and pathogens: a meta-analysis. Global Change Biology 18:267-276.

Jimenez, E., J. A. Vega, P. Perez-Gorostiaga, P. Cuinas, T. Fonturbel, C. Fernandez, J. Madrigal, C. Hernando, and M. Guijarro. 2008. Effects of pre-commercial thinning on transpiration in young post-fire maritime pine stands. Forestry 81:543-557.

Jung, E. Y., D. Otieno, B. Lee, J. H. Lim, S. K. Kang, M. W. T. Schmidt, and J. Tenhunen. 2011. Up-scaling to stand transpiration of an Asian temperate mixed-deciduous forest from single tree sapflow measurements. Plant Ecology 212:383-395.

Kharuk, V. I., K. J. Ranson, P. A. Oskorbin, S. T. Im, and M. L. Dvinskaya. 2013. Climate induced birch mortality in Trans-Baikal lake region, Siberia. Forest Ecology and Management 289:385-392.

Kumagai, T., and A. Porporato. 2012. Drought-induced mortality of a Bornean tropical rain forest amplified by climate change. Journal of Geophysical Research-Biogeosciences 117:1-13.

Kume, T., K. Tsuruta, H. Komatsu, T. Kumagai, N. Higashi, Y. Shinohara, and K. Otsuki. 2010. Effects of sample size on sap flux-based stand-scale transpiration estimates. Tree Physiology 30:129-138.

Lagergren, F., H. Lankreijer, J. Kučera, E. Cienciala, M. Mölder, and A. Lindroth. 2008. Thinning effects on pinespruce forest transpiration in central Sweden. Forest Ecology and Management 255:2312-2323.

Lesch, W., and D. F. Scott. 1997. The response in water yield to the thinning of Pinus radiata, Pinus patula and Eucalyptus grandis plantations. Forest Ecology and Management 99:295-307.

Levesque, M., M. Saurer, R. Siegwolf, B. Eilmann, P. Brang, H. Bugmann, and A. Rigling. 2013. Drought response of five conifer species under contrasting water availability suggests high vulnerability of Norway spruce and European larch. Global Change Biology 19:3184-3199.

Lindner, M. 2000. Developing adaptive forest management strategies to cope with climate change. Tree Physiology 20:299-307.

Logan, J., and B. Bentz. 1987. Model analysis of mountain pine beetle (Coleoptera: Scolytidae) seasonality. Environmental Entomology 28:924-934.

Macfarlane, C., C. Bond, D. A. White, A. H. Grigg, G. N. Ogden, and R. Silberstein. 2010. Transpiration and hydraulic traits of old and regrowth eucalypt forest in southwestern Australia. Forest Ecology and Management 260:96-105.

Magnani, F., J. Grace, and M. Borghetti. 2002. Adjustment of tree structure in response to the environment under hydraulic constraints. Functional Ecology 16:385-393.

Matusick, G., K. X. Ruthrof, N. C. Brouwers, B. Dell, and G. S. J. Hardy. 2013. Sudden forest canopy collapse corresponding with extreme drought and heat in a mediterranean-type eucalypt forest in southwestern Australia. European Journal of Forest Research 132:497-510. 
McDowell, N. G., H. D. Adams, J. D. Bailey, M. Hess, and T. E. Kolb. 2006. Homeostatic maintenance of ponderosa pine gas exchange in response to stand density changes. Ecological Applications 16:1164-1182.

McDowell, N. G., D. J. Beerling, D. D. Breshears, R. A. Fisher, K. F. Raffa, and M. Stitt. 2011. The interdependence of mechanisms underlying climate-driven vegetation mortality. Trends in Ecology \& Evolution 26:523-532.

McJannet, D., and R. Vertessy. 2001. Effects of thinning on wood production, leaf area index, transpiration and canopy interception of a plantation subject to drought. Tree Physiology 21:1001-1008.

Meinshausen, M., et al. 2011. The RCP greenhouse gas concentrations and their extensions from 1765 to 2300. Climatic Change 109:213-241.

Mencuccini, M., and L. Bonosi. 2001. Leaf/sapwood area ratios in Scots pine show acclimation across Europe. Canadian Journal of Forest Research 31:442-456.

Mencuccini, M., and J. Grace. 1995. Climate influences the leaf area/sapwood area ratio in Scots pine. Tree Physiology 15:110.

Michaelian, M., E. H. Hogg, R. J. Hall, and E. Arsenault. 2011. Massive mortality of aspen following severe drought along the southern edge of the Canadian boreal forest. Global Change Biology 17:2084-2094.

Montero, G., I. Canellas, C. Ortega, and M. Del Rio. 2001. Results from a thinning experiment in a Scots pine (Pinus sylvestris L.) natural regeneration stand in the Sistema Iberico Mountain Range (Spain). Forest Ecology and Management 145:151-161.

Moreno, G., and E. Cubera. 2008. Impact of stand density on water status and leaf gas exchange in Quercus ilex. Forest Ecology and Management 254:74-84.

Morikawa, Y., S. Hattori, and Y. Kiyono. 1986. Transpiration of a 31-year-old Chamaecyparis obtusa Endl. stand before and after thinning. Tree Physiology 2:105-114.

Nakicenovic, N., et al. 2000. IPCC special report on emissions scenarios. Cambridge University Press, Cambridge, UK.

Neill, A. R., and K. J. Puettmann. 2013. Managing for adaptive capacity: thinning improves food availability for wildlife and insect pollinators under climate change conditions. Canadian Journal of Forest Research 43:428-440.

Niinemets, U. 2010. Responses of forest trees to single and multiple environmental stresses from seedlings to mature plants: past stress history, stress interactions, tolerance and acclimation. Forest Ecology and Management 260:16231639.

O'Grady, A. P., P. G. Cook, D. Eamus, A. Duguid, J. D. H. Wischusen, T. Fass, and D. Worldege. 2009. Convergence of tree water use within an arid-zone woodland. Oecologia 160:643-655.

Olson, M. G., S. R. Meyer, R. G. Wagner, and R. S. Seymour. 2014. Commercial thinning stimulates natural regeneration in spruce-fir stands. Canadian Journal of Forest Research 44:173-181.

Otto, R., E. Garcia-del-Rey, J. Mendez, and J. Maria Fernandez-Palacios. 2012. Effects of thinning on seed rain, regeneration and understory vegetation in a Pinus canariensis plantation (Tenerife, Canary Islands). Forest Ecology and Management 280:71-81.

Parks, C. G., and P. Bernier. 2010. Adaptation of forests and forest management to changing climate with emphasis on forest health: a review of science, policies and practices. Forest Ecology and Management 259:657-659.

Pechony, O., and D. T. Shindell. 2010. Driving forces of global wildfires over the past millennium and the forthcoming century. Proceedings of the National Academy of Sciences USA 107:19167-19170.

Prentice, I. C., M. T. Sykes, and W. Cramer. 1993. A simulation-model for the transient effects of climate change on forest landscapes. Ecological Modelling 65:51-70.
Pretzsch, H., G. Schutze, and E. Uhl. 2013. Resistance of European tree species to drought stress in mixed versus pure forests: evidence of stress release by inter-specific facilitation. Plant Biology 15:483-495.

Rasche, L., L. Fahse, A. Zingg, and H. Bugmann. 2012. Enhancing gap model accuracy by modeling dynamic height growth and dynamic maximum tree height. Ecological Modelling 232:133-143.

Rebetez, M., and M. Dobbertin. 2004. Climate change may already threaten Scots pine stands in the Swiss Alps. Theoretical and Applied Climatology 79:1-9.

Rebetez, M., H. Mayer, O. Dupont, D. Schindler, K. Gartner, J. P. Kropp, and A. Menzel. 2006. Heat and drought 2003 in Europe: a climate synthesis. Annals of Forest Science 63:569577.

Rigling, A., et al. 2013. Driving factors of a vegetation shift from Scots pine to pubescent oak in dry Alpine forests. Global Change Biology 19:229-240.

Rigling, A., P. Weber, T. Wohlgemuth, R. Zweifel, and M. Dobbertin. 2010. Direct und indirect effects of drought in large-scale pine dieback in the European Alps. International Forestry Review 12:65.

Río, M., R. Calama, I. Cañellas, S. Roig, and G. Montero. 2008. Thinning intensity and growth response in SWEuropean Scots pine stands. Annals of Forest Science 65:308.

Rossler, O., B. Diekkruger, and J. Loffler. 2012. Potential drought stress in a Swiss mountain catchment - ensemble forecasting of high mountain soil moisture reveals a drastic decrease, despite major uncertainties. Water Resources Research 48. http://dx.doi.org/10.1029/2011WR011188

Sarkkola, S., M. Nieminen, E. Ahti, H. Hökkä, H. Koivusalo, J. Päivänen, and J. Laine. 2010. Role of tree stand evapotranspiration in maintaining satisfactory drainage conditions in drained peatlands. Canadian Journal of Forest Research 40:1485-1496.

Schar, C., P. L. Vidale, D. Luthi, C. Frei, C. Haberli, M. A. Liniger, and C. Appenzeller. 2004. The role of increasing temperature variability in European summer heatwaves. Nature 427:332-336.

Schonenberger, W., A. Noack, and P. Thee. 2005. Effect of timber removal from windthrow slopes on the risk of snow avalanches and rockfall. Forest Ecology and Management 213:197-208.

Schumacher, S., and H. Bugmann. 2006. The relative importance of climatic effects, wildfires and management for future forest landscape dynamics in the Swiss Alps. Global Change Biology 12:1435-1450.

Schumacher, S., H. Bugmann, and D. J. Mladenoff. 2004. Improving the formulation of tree growth and succession in a spatially explicit landscape model. Ecological Modelling 180:175-194.

Schumacher, S., B. Reineking, J. Sibold, and H. Bugmann. 2006. Modeling the impact of climate and vegetation on fire regimes in mountain landscapes. Landscape Ecology 21:539554.

Schuster, R., and W. Oberhuber. 2013. Drought sensitivity of three co-occurring conifers within a dry inner Alpine environment. Trees 27:61-69.

Seidl, R., W. Rammer, P. Lasch, F. W. Badeck, and M. J. Lexer. 2008. Does conversion of even-aged, secondary coniferous forests affect carbon sequestration? A simulation study under changing environmental conditions. Silva Fennica 42:369-386.

Seidl, R., W. Rammer, and M. J. Lexer. 2011a. Adaptation options to reduce climate change vulnerability of sustainable forest management in the Austrian Alps. Canadian Journal of Forest Research 41:694-706.

Seidl, R., M.-J. Schelhaas, and M. J. Lexer. 2011b. Unraveling the drivers of intensifying forest disturbance regimes in Europe. Global Change Biology 17:2842-2852. 
Seneviratne, S. I., et al. 2012. Changes in climate extremes and their impacts on the natural physical environment. Pages 109-230 in C. B. Field et al., editors. Managing the risks of extreme events and disasters to advance climate change adaptation. Cambridge University Press, Cambridge, UK.

Shuman, B., A. K. Henderson, C. Plank, I. Stefanova, and S. S. Ziegler. 2009. Woodland-to-forest transition during prolonged drought in Minnesota after ca. AD 1300. Ecology 90:2792-2807.

Sohn, J. A., T. Gebhardt, C. Ammer, J. Bauhus, K. H. Häberle, R. Matyssek, and T. E. E. Grams. 2013. Mitigation of drought by thinning: short-term and long-term effects on growth and physiological performance of Norway spruce (Picea abies). Forest Ecology and Management 308:188-197.

Stogsdill, W. R., R. F. Wittwer, T. C. Hennessey, and P. M. Dougherty. 1992. Water use in thinned loblolly pine plantations. Forest Ecology and Management 50:233-245.

Sun, G., A. Noormets, J. Chen, and S. G. McNulty. 2008. Evapotranspiration estimates from eddy covariance towers and hydrologic modeling in managed forests in Northern Wisconsin, USA. Agricultural and Forest Meteorology 148:257-267.

Temperli, C., H. Bugmann, and C. Elkin. 2012. Adaptive management for competing forest goods and services under climate change. Ecological Applications 22:2065-2077.

Temperli, C., H. K. M. Bugmann, and C. Elkin. 2013. Crossscale interactions among bark beetles, climate change and wind disturbances: a landscape modeling approach. Ecological Monographs 83:383-402.

Vacchiano, G., M. Garbarino, E. B. Mondino, and R. Motta. 2012. Evidences of drought stress as a predisposing factor to Scots pine decline in Valle d'Aosta (Italy). European Journal of Forest Research 131:989-1000.

van der Linden, P., and J. F. B. Mitchell, editors. 2009. ENSEMBLES: climate change and its impacts: summary of research and results from the ENSEMBLES project. Met Office Hadley Centre, Exeter, UK.

Vesala, T., et al. 2005. Effect of thinning on surface fluxes in a boreal forest. Global Biogeochemical Cycles 19:GB2001.

Vicente-Serrano, S. M., et al. 2013. Response of vegetation to drought time-scales across global land biomes. Proceedings of the National Academy of Sciences USA 110:52-57.

von Detten, R. 2011. Sustainability as a guideline for strategic planning? The problem of long-term forest management in the face of uncertainty. European Journal of Forest Research 130:451-465.

Weber, P., H. Bugmann, P. Fonti, and A. Rigling. 2008. Using a retrospective dynamic competition index to reconstruct forest succession. Forest Ecology and Management 254:96106.

Weber, P., H. Bugmann, and A. Rigling. 2007. Radial growth responses to drought of Pinus sylvestris and Quercus pubescens in an inner-Alpine dry valley. Journal of Vegetation Science 18:777-792.

Wermelinger, B., A. Rigling, D. S. Mathis, and M. Dobbertin. 2008. Assessing the role of bark- and wood-boring insects in the decline of Scots pine (Pinus sylvestris) in the Swiss Rhone valley. Ecological Entomology 33:239-249.

Wermelinger, B., and M. Seifert. 1999. Temperature-dependent reproduction of the spruce bark beetle Ips typographus, and analysis of the potential population growth. Ecological Entomology 24:103-110.

Whitley, R., D. Taylor, C. Macinnis-Ng, M. Zeppel, I. Yunusa, A. O'Grady, R. Froend, B. Medlyn, and D. Eamus. 2013. Developing an empirical model of canopy water flux describing the common response of transpiration to solar radiation and VPD across five contrasting woodlands and forests. Hydrological Processes 27:1133-1146.

Williams, A. P., et al. 2013. Temperature as a potent driver of regional forest drought stress and tree mortality. Nature Climate Change 3:292-297.

Williams, A. P., C. D. Allen, C. I. Millar, T. W. Swetnam, J. Michaelsen, C. J. Still, and S. W. Leavitt. 2010. Forest responses to increasing aridity and warmth in the southwestern United States. Proceedings of the National Academy of Sciences USA 107:21289-21294.

Xu, X., S. Piao, X. Wang, A. Chen, P. Ciais, and R. B. Myneni. 2012. Spatio-temporal patterns of the area experiencing negative vegetation growth anomalies in China over the last three decades. Environmental Research Letters 7:1-9.

Zeppel, M. 2013. Convergence of tree water use and hydraulic architecture in water-limited regions: a review and synthesis. Ecohydrology 6:889-900.

Zou, C. B., D. D. Breshears, B. D. Newman, B. P. Wilcox, M. O. Gard, and P. M. Rich. 2008. Soil water dynamics under low- versus high-ponderosa pine tree density: ecohydrological functioning and restoration implications. Ecohydrology 1:309-315.

Zumbrunnen, T., H. Bugmann, M. Conedera, and M. Burgi. 2009. Linking forest fire regimes and climate - a historical analysis in a dry inner alpine valley. Ecosystems 12:73-86.

Zweifel, R., A. Rigling, and M. Dobbertin. 2009. Speciesspecific stomatal response of trees to drought - a link to vegetation dynamics? Journal of Vegetation Science 20:442454.

\section{Supplemental Material}

Ecological Archives

The Appendix is available online: http://dx.doi.org/10.1890/14-0690.1.sm

\section{Data Availability}

Data associated with this paper have been deposited in ETH Zurich's Data Archive: http://dx.doi.org/10.5905/ethz-1007-12 